\title{
Synthesis and Biomedical Application of Hydroxyapatite as Carrier for Loading and Controlled Delivery of Antibiotics
}

\author{
MARIANA MATEESCU SANDA MARIA DONCEA, IULIANA RAUT, CRISTINA LAVINIA NISTOR, IONETA CODRINA BUJ ANCA* \\ National R\&D Institute for Chemistry and Petrochemistry, 202 Splaiul Independencei, 060021, Bucharest, Romania
}

\begin{abstract}
The hydroxyapatite (HA) nano and microparticles were synthesized by wet-chemical precipitation in order to use them as drug carriers for biomedical applications. Scanning Electron Microscopy (SEM), Dynamic Light Scattering (DLS) and Fourier Transform Infrared Spectroscopy (FTIR) were performed to assess their size, external morphology and chemical composition. The properties of HA particles as drug carriers for antibiotics delivery were evaluated with doxycycline and chloramphenicol. The amount of drug loading and release was determined by UV-Visible spectrophotometry. The antibacterial properties of loaded HA particles were evaluated using gram-positive Bacillus subtilis bacteria and gram-negative Pseudomonas aeruginosa bacteria. The synthesized particles of HA exhibit a high adsorption capacity (around 99\%) and good controlled release properties for doxycycline. The adsorption of chloramphenicol on HA was extremely low (about $2 \%)$. According to the results, the compatibility between the drug and substrate is an important factor in the absorption process, and the hydroxyapatite is a very promising carrier for controlled release of antibiotics.
\end{abstract}

Keywords: hydroxyapatite synthesis, drug carrier, drug release, antibacterial activity, doxycycline, chloramphenicol

The study of micro and nanoparticles in biomedicine has an important role in the development of new generation of drug delivery systems. Micro and nano-sized particles are especially desirable over conventional drug carrier due to their high specific surface areas which allow an excellent drug loading capacity and a controlled drug release. Additionally, these drug delivery systems have the advantages of improving the therapeutic efficacy by providing a constant drug concentration in blood, concomitant with a reduction in the drug intake and its toxic effect.

Hydroxyapatite $\left(\mathrm{Ca}_{10}\left(\mathrm{PO}_{4}\right)_{6}(\mathrm{OH})_{2}, \mathrm{HA}\right)$ is a natural inorganic compound which is found in the hard tissues of bones and teeth of vertebrates. Due to its biocompatibility, bioactivity and nontoxicity, nano and micro-size HA particles have been successfully used in medical and pharmaceutical fields as material in bone tissue engineering [1] and drug delivery systems for proteins [2], genes [3], antibiotics [4-6], and other drugs [7].

Various techniques have been utilized to prepare nano and micro-size HA particles, including solid-state reaction process [8], hydrothermal precipitation method [9], microemulsion process [10], spray drying [11], and wetchemical precipitation [12-17]. Among these methods, wet chemical process is generally preferred because is a simple technique, offers a rapid synthesis and has a low cost for industrial production. In addition, this method has the advantage that the reaction media is devoid of extraneous elements and water is the only by-product. In these conditions, it is of great importance in the process of HA synthesis to focus on the precise control of particle size, morphology and chemical composition.

In the present work, the wet-chemical precipitation method has been used to obtain nano and micro-sized HA particles. Their structural and morphological properties were investigated by Scanning Electron Microscopy (SEM), Dynamic Light Scattering (DLS) and Fourier Transform Infrared Spectroscopy (FTIR). The potential of the synthesized HA as drug carrier was evaluated from adsorption and release experiments using doxycycline and chloramphenicol antibiotics. The amount of drug loaded

*email: codrina.bujanca@icechim.ro and delivered was detected by ultraviolet-visible (UV-vis) spectrophotometry. The antimicrobial activity of loaded antibiotic was evaluated using Bacillus subtilis and Pseudomonas aeruginosa bacteria.

\section{Experimental part}

Materials

High purity calcium nitrate tetrahydrate $\left(\mathrm{Ca}\left(\mathrm{NO}_{3}\right), \mathrm{Y}_{4} \mathrm{H}_{2} \mathrm{O}\right)$, ammonium phosphate dibasic $\left(\left(\mathrm{NH}_{4}\right)_{2} \mathrm{HPO}_{4}\right)$, and ammonia solution were used for the preparation of HA (Sigma Aldrich Chemicals). Two antibiotics, doxycycline hyclate (Sigma Aldrich, figure 6) and chloramphenicol (ACROS ORGANICS Chemicals, fig. 7), were used for adsorption and desorption studies. The chemicals, sodium hydroxide $(\mathrm{NaOH})$ and potassium phosphate monobasic $\left(\mathrm{KH}_{2} \mathrm{PO}_{4}\right)$ were purchased from Scharlau Chemicals. Phosphate-buffered saline solution (PBS) of $p \mathrm{H}=7.4\left(0.2 \mathrm{M} \mathrm{NaOH} / 0.2 \mathrm{M} \mathrm{KH}_{2} \mathrm{PO} \mathrm{K}\right)$ were prepared in double distilled water. All chemicals were of analytical grades and used as received, without further purification. The bacterial strains of Bacillus subtilis and Pseudomonas aeruginosa were provided by the Microorganism Collection of our Microbiology Laboratory (of National $R \& D$ Institute for Chemistry and Petrochemistry -ICECHIM Bucharest).

\section{Synthesis of HA particles}

HA powder samples were prepared by wet chemical precipitation as previously described [17]. Briefly, $250 \mathrm{~mL}$ of calcium nitrate tetrahydrate solution (1 M) was added drop-wise to $250 \mathrm{~mL}$ of ammonium phosphate dibasic solution (0.6 M) while stirring for one hour (1h) at room temperature. The $\mathrm{pH}$ of the system was maintained at 11 throughout the stirring process by using $25 \%$ ammonia solution. The obtained precipitate solution was stirred $1 \mathrm{~h}$ for homogenization, refluxed at $100^{\circ} \mathrm{C}$ for another hour, and then was left to rest overnight. The precipitate was washed and filtered on filter paper under vacuum. The white precipitate formed was dried in an oven at $80^{\circ} \mathrm{C}$ for $24 \mathrm{~h}$. The powder was crushed in a mortar and subsequently subjected to calcinations in platinum crucibles at $800^{\circ} \mathrm{C}$ 
for $1 \mathrm{~h}$, at $1000^{\circ} \mathrm{C}$ for $2 \mathrm{~h}$ and at $1200^{\circ} \mathrm{C}$ for $4 \mathrm{~h}$. The prepared pow ders were mixed and used for further characterization. To see the reproduction of this approach, we made another batch of HA powders, under the same conditions. HAl and HA2 labels were utilized to differentiate between the experiments.

\section{Antibiotic loading on $\mathrm{HA}$}

Doxycycline hyclate and chloramphenicol solutions were used as water soluble models. In order to estimate the adsorptive amount of antibiotic on HA, $0.5 \mathrm{~g}$ of $\mathrm{HA}$ powder was immersed into $75 \mathrm{~mL}$ of antibiotics at different concentrations ( 1 and $2 \mathrm{mg} / \mathrm{mL}$ ). The resulted suspension was stirred $(250 \mathrm{rpm})$ for various time periods $(6,24,30$, $54,78,102,126,150,174 \mathrm{~h}$ ) at room temperature. The suspension was then centrifuged at $5000 \mathrm{rpm}$ for $30 \mathrm{~min}$. The supernatant was measured by UV-Vis spectrometer at a wavelength of $350 \mathrm{~nm}$ for doxycycline and $278 \mathrm{~nm}$ for chloramphenicol. The amount of loaded antibiotic was calculated by the difference in the drug concentration before and after adsorption using the equation:

$$
\text { Drug loading } \%=\frac{C_{i}-C_{f}}{C_{i}} \times 100
$$

where $\mathrm{C}_{i}$ and $\mathrm{C}_{f}$ are the initial and the final drug concentration of the aqueous antibiotic solution, $\mathrm{mg} / \mathrm{mL}$.

The sediment of the antibiotic-loaded hydroxyapatite was lyophilized for $24 \mathrm{~h}$ and then used in further investigations.

\section{In vitro drug release}

The release study was carried out by dispersing $0.1 \mathrm{~g}$ of antibiotics loaded HA particles into a test tube with a stopper containing $50 \mathrm{~mL}$ of phosphate buffer medium at $37^{\circ} \mathrm{C}$ and $\mathrm{pH}$ 7.4. The experiments were performed under stirring at $200 \mathrm{rpm}$ for a period of $242 \mathrm{~h}$. At the predetermined sampling times, the tube was removed and centrifuged at $5000 \mathrm{rpm}$ for $30 \mathrm{~min}$. About $5 \mathrm{~mL}$ of supernatant was withdrawn for antibiotics determination and replaced with $5 \mathrm{~mL}$ fresh PBS. The amount of antibiotic from the supernatant was determined by UV-Vis spectrophotometric method.

\section{In vitro antibacterial studies}

The antibacterial activity of doxycycline was performed against the Bacillus subtilis and Pseudomonas aeruginosa. The bacterial strains were inoculated on Luria-Bertani (LB) medium and were incubated for $48 \mathrm{~h}$ at $37^{\circ} \mathrm{C}$.

In order to standardize the bacterial inoculum, the growth rates of bacteria were monitored by determining the optical density (OD) with a spectrophotometer BIOM at a wavelength of $590 \mathrm{~nm}$. Petri plates were seeded with a suspension with an OD of 0.140 , which corresponds to a concentration of $1.95 \times 108 \mathrm{CFU} / \mathrm{mL}$. (CFU = colony

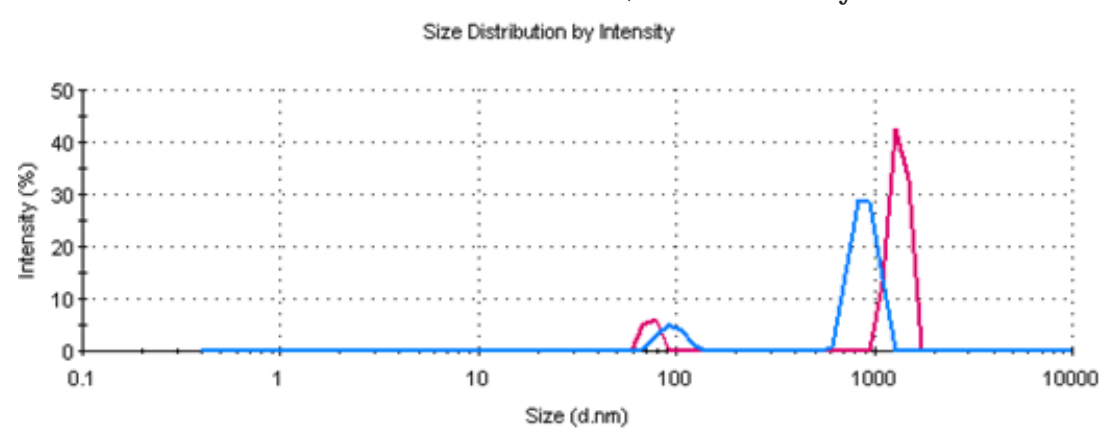

forming units; the number of viable germs of the material examined).

For the determination of antibacterial activity of the hydroxyapatite powders, two biochemical compounds containing 1 and $2 \mathrm{mg} / \mathrm{mL}$ doxycycline loaded hydroxyapatite were used. Then from each biochemical compound, samples of $200 \mathrm{mg}, 500 \mathrm{mg}$ and $2300 \mathrm{mg}$ were suspended in $1 \mathrm{~mL}$ of bidistilled water into Eppendorf test tubes. Paper disks with a diameter of $6 \mathrm{~mm}$ were placed on the surface of the solid culture medium in the Petri dish and impregnated with a $25 \mathrm{~mL}$ solution of compound withdrawn from the suspension in the Eppendorf test tubes. The Petri dishes were incubated at $37^{\circ} \mathrm{C}$ for $72 \mathrm{~h}$. The bacterial cultures were microscopically observed and the antimicrobial activity was evaluated by measuring the inhibition zone of the tested microorganism on two perpendicular axes at 24, 48 and $72 \mathrm{~h}$. Experiments were performed in triplicate.

\section{Characterization}

The chemical nature and the molecular bond structure of the samples were determined by using a FT-IR spectrometer (Perkin Elmerm Spectrum GX). The measuring resolution was $4 \mathrm{~cm}^{-1}$ and the spectral range was $400-4000 \mathrm{~cm}^{-1}$.

The particle size analyses of the pure HA were investigated by dynamic light scattering (DLS) technique using a Nano ZS (Red badge) instrument. Prior to the DLS measurements, $0.01 \mathrm{~g}$ of the sample was suspended in 25 $\mathrm{mL}$ distilled water and sonicated for $5 \mathrm{~min}$.

The morphology of the HA particles was observed by scanning electron microscopy using Environmental Scanning Electron Microscope (ESEM) FEI Quanta 200.

The amount of drug in the adsorption and desorption studies was determined by using a UV-VIS spectrophotometer CINTRA 202.

\section{Results and discussions}

\section{Dynamic Light Scattering measurement}

The DLS image (fig. 1) shows small particles with a mean diameter of about 70-90 $\mathrm{nm}$ and particles with an average size of $900-1200 \mathrm{~nm}$.

\section{Scanning Electron Microscopy}

The SEM images of the synthetized HA powders revealed a spherical morphology of the agglomerated particles with sizes around $1 \mu \mathrm{m}$ (fig. $2 \mathrm{a}, \mathrm{b}$ ).

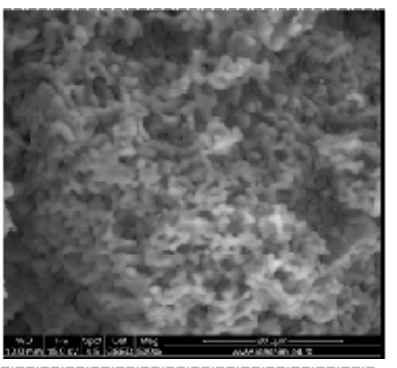

a

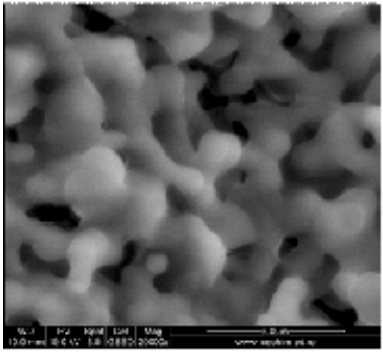

b

Fig. 2. SEM images of synthetized HA 


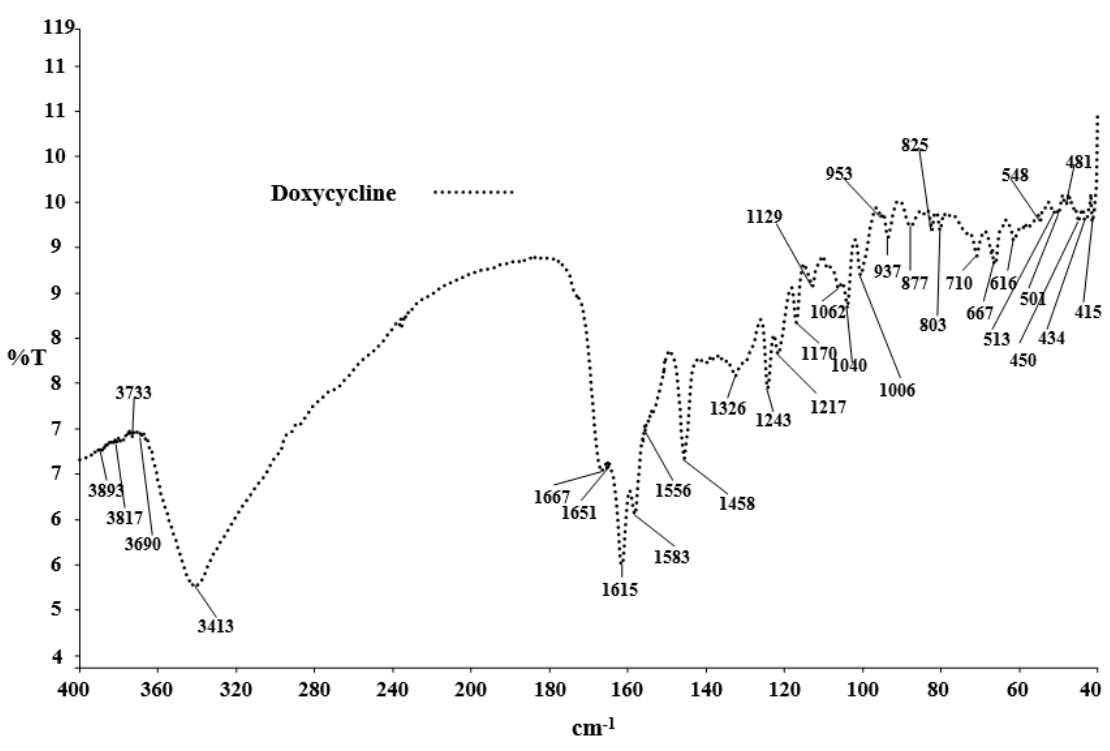

Fig. 3. FTIR spectrum of doxycycline

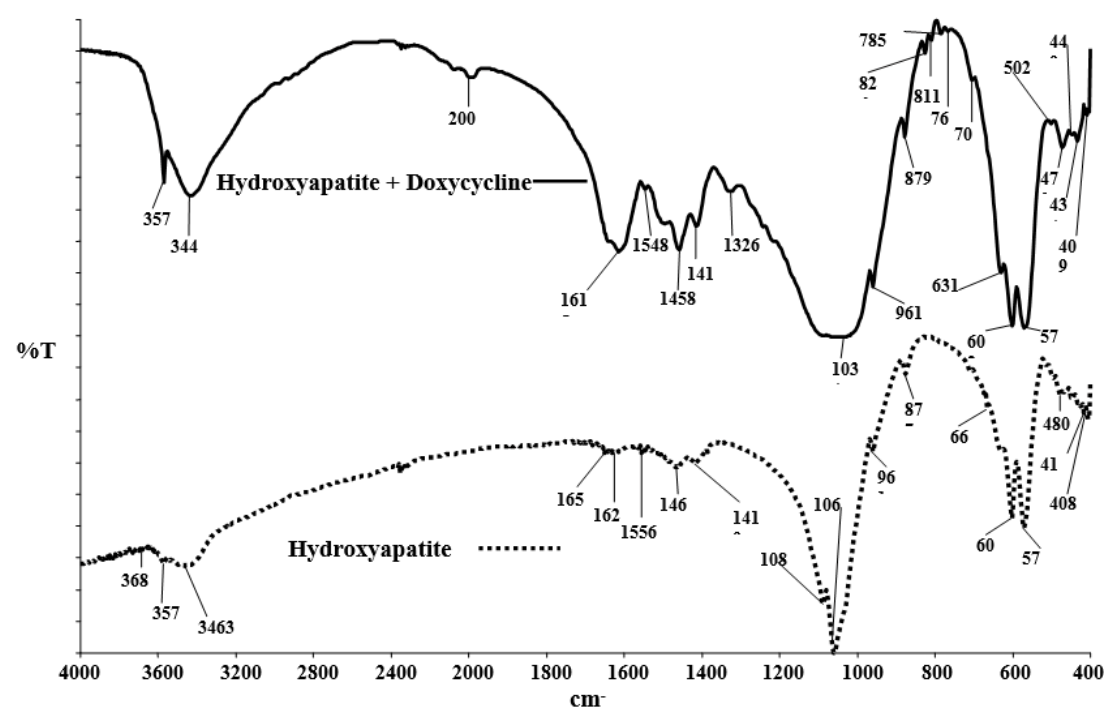

Fig. 4. FTIR spectrum of microstructurated hydroxyapatite and doxycycline doped hydroxyapatite

\section{FTIR spectroscopy}

The FTIR spectra of pure doxycycline, microstructurated hydroxyapatite, and doxycycline loaded hydroxyapatite are given in the figures 3 and 4.

As seen in figure 3 , the main characteristic absorption bands of doxycycline are at $3690 \mathrm{~cm}^{-1}$ and at $3413 \mathrm{~cm}^{-1}$ for- $\mathrm{OH}$ groups, at $1667 \mathrm{~cm}^{-1}$ and $1651 \mathrm{~cm}^{-1}$ for $\mathrm{C}=0$ of Amide I group. The band at $1615 \mathrm{~cm}^{-1}$ is specific for $-\mathrm{COOH}$ group, and the bands at $1583 \mathrm{~cm}^{-1}$ and $1556 \mathrm{~cm}^{-1}$ are specific to $\mathrm{NH}$ from Amide II group. The bands at 1458 $\mathrm{cm}^{-1}$ and $1326 \mathrm{~cm}^{-1}$ are characteristic to $-\mathrm{CH}_{2}$ group. In the spectrum of doxycycline, the vibration transmittance band at $1243 \mathrm{~cm}^{-1}$ is ascribed to $\mathrm{NH}$ from Amide III group. The C0 group transmittance band, attached to hydrocarbons ring, at $1170 \mathrm{~cm}^{-1}, 1062 \mathrm{~cm}^{-1}, 1040 \mathrm{~cm}^{-1}$ and $1006 \mathrm{~cm}^{-1}$, are also specific to doxycycline.

The figure 4 displays the FTIR spectrum of doxycycline doped hydroxyapatite compared with the FTIR spectrum of hydroxyapatite For the spectrum of hydroxyapatite, transmittance bands at $3575 \mathrm{~cm}^{-1}$ and at $3463 \mathrm{~cm}^{-1}$ emphasize the presence of $-\mathrm{OH}$, at $1089 \mathrm{~cm}^{-1}, 1061 \mathrm{~cm}^{-1}$, $961 \mathrm{~cm}^{-1}, 603 \mathrm{~cm}^{-1}$, and $573 \mathrm{~cm}^{-1}$ the bands characteristic to $\mathrm{PO}_{4}^{3-}$, at $668 \mathrm{~cm}^{-1}$ for $\mathrm{HPO}_{4}^{3-}$, and the transmittance bands at $1419 \mathrm{~cm}^{-1}$ and $877 \mathrm{~cm}^{-1}$ correspond to $\mathrm{CO}_{3}{ }^{2-}$ anion due to the $\mathrm{CO}_{2}$ adsorption from the atmosphere into $\mathrm{HA}$ particles. The characteristic transmittance bands associated with doxycycline at $1615 \mathrm{~cm}^{-1}$, at $1548 \mathrm{~cm}^{-1}$, at $1458 \mathrm{~cm}^{-1}$ and at $1326 \mathrm{~cm}^{-1}$ in the Hydroxyapatite + Doxycycline spectrum indicate the adsorption of doxycycline on the HA. This is a physical process and the properties of doxycycline are preserved during the adsorption phenomenon, an important behaviour for a controlled drug release application.

\section{Drug loading and release studies}

The data of the drug loading study are shown in figure 5 . The drug loading efficiency of hydroxyapatite has been found to depend on the adsorption time and the chemical structure of antibiotics. It was observed that doxycycline has an excellent adsorption capacity on hydroxyapatite particles. The adsorption equilibrium was attained after $100 \mathrm{~h}$ (and before $126 \mathrm{~h}$, our measurements). After $174 \mathrm{~h}$, a maximum of $1.979 \mathrm{mg} / \mathrm{mL}$ doxycycline $(99 \%$ from the initial solution of $2 \mathrm{mg} / \mathrm{mL}$ of doxycycline) and $0.998 \mathrm{mg} /$ $\mathrm{ml}$ doxycycline ( $99 \%$ of the $1 \mathrm{mg} / \mathrm{mL}$ solution) was loaded on the HA particles.

The capacity of chloramphenicol loading on hydroxyapatite was very low. After $174 \mathrm{~h}$, a maximum of $2 \%$ chloramphenicol was adsorbed on $\mathrm{HA}$.

The greater adsorption affinity of doxycycline on hydroxyapatite could be explained due to the chemical structure of doxycycline (fig. 6) and its compatibility with the HA particles, with various possibilities to form electrostatic interactions: hydrogen bonding between hydroxyl groups of doxycycline and hydroxyapatite, or 


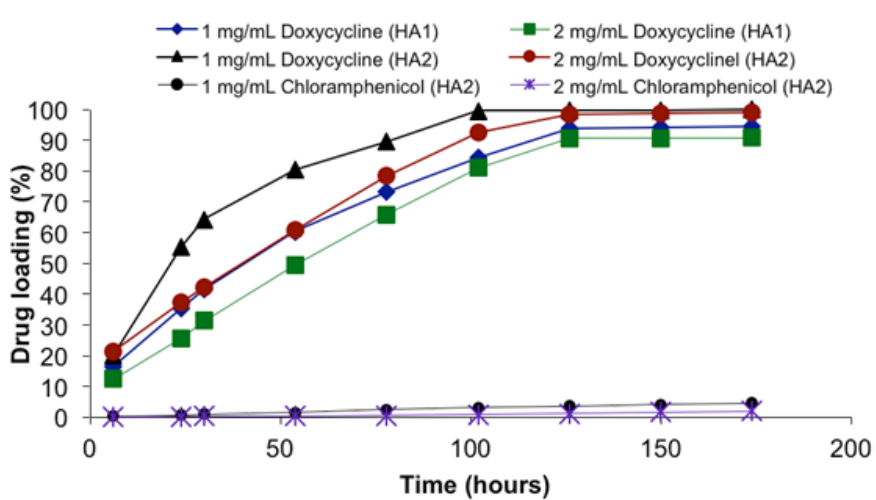

Fig. 5. Percentage of drug loaded onto hydroxyapatite as a function of time

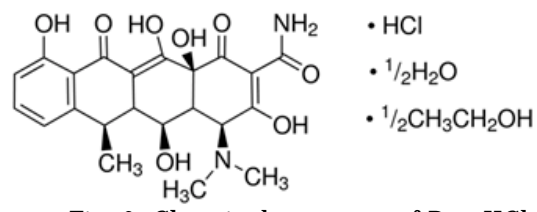

Fig. 6. Chemical structure of Dox. HCl

between hydroxyl groups of the hydroxyapatite and the unshared electrons of the oxygen (of the carbonyl group) and the nitrogen of doxycycline.

Chloramphenicol (fig. 7) has almost no affinity for HA particles. This could be explained due to a low solubility in<smiles>NN(C(=O)C(Cl)Cl)[C@H](CO)[C@H](O)c1ccc([N+](=O)[O-])cc1</smiles>

Fig. 7. Chemical structure of Chloramphenicol

water $(2.5 \mathrm{~g} / \mathrm{L})$ and less potential to form electrostatic interactions, with hydrogen bonding with the $\mathrm{OH}$ groups of hydroxyapatite.

The loaded hydroxyapatite exhibits a sustained and slow release of the drug, which prevents the burst release of doxycycline and prolongs the drug effect (fig. 8). This behavior could be attributed to the fact that a high amount of doxycycline was adsorbed in the channels of the porous HA and a small amount of doxycycline was attached to the surface of the HA particles. The more drug in the channels of HA, the slower the desorption process. The doxycycline release after $242 \mathrm{~h}$ was $36 \%$ from the 0.998 $\mathrm{mg} / \mathrm{mL}$ antibiotic solution and $55 \%$ from the $1.979 \mathrm{mg} / \mathrm{mL}$ drug-loaded sample. The results demonstrate that HA

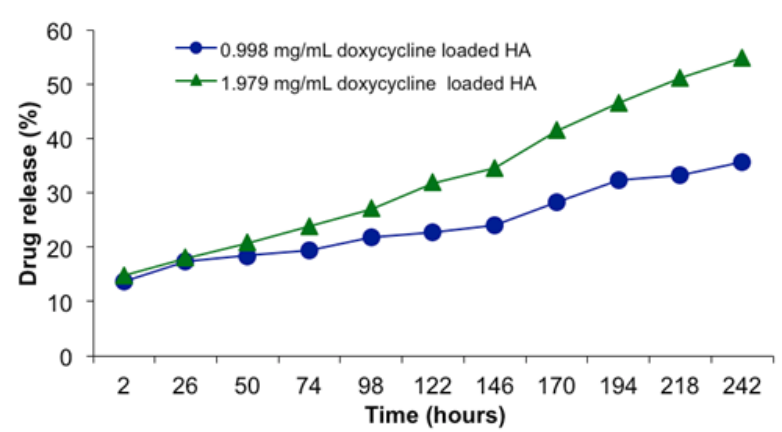

Fig. 8. The release profile of doxycycline from hydroxyapatite

could be used as a carrier for a compatible drug when a slow rate of release over a long period is desired.

Antibacterial activity

The results of the antibacterial activity of doxycyclineloaded hydroxyapatite are given in table 1 . The zone of inhibition around the pure hydroxyapatite and doxycyclineloaded hydroxyapatite against Bacillus subtilis and Pseudomonas aeruginosa is shown in the figures 9,10 and 11.

As seen in figure 9 , the compound $A$, loaded with about $1 \mathrm{mg} / \mathrm{mL}$ doxycycline, has an antibacterial effect against Bacillus subtilis, even at the lowest amount of biochemical compound $(200 \mathrm{mg})$. This effect is seen after an incubation of $48 \mathrm{~h}$ increases in intensity towards $72 \mathrm{~h}$. The strain of Pseudomonas aeruginosa is not sensitive to the action of Compound A.

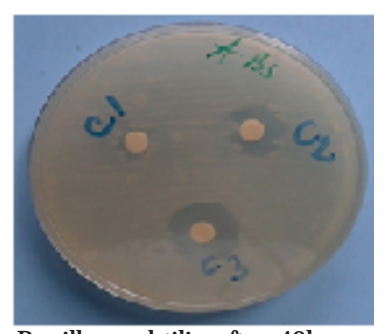

Bacillus subtilis after $48 \mathrm{~h}$

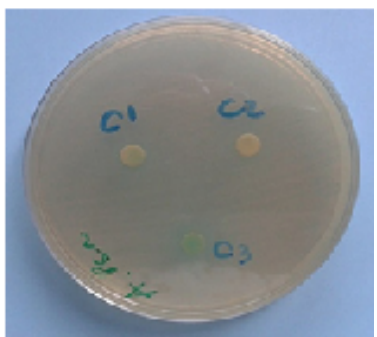

Pseudomonas aeruginosa after $48 \mathrm{~h}$

Fig. 9. The inhibitory effect of compound A (HA loaded with about 1 $\mathrm{mg} / \mathrm{mL}$ doxycycline) against the growth of the bacterial strains
Pseudomonas aeruginosa after $72 \mathrm{~h}$
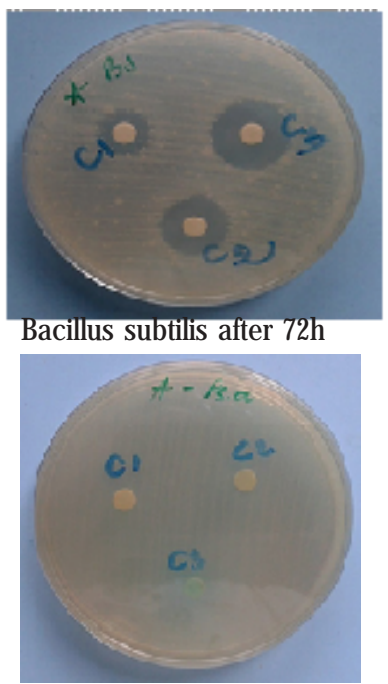

\begin{tabular}{|c|c|c|c|c|}
\hline \multicolumn{5}{|c|}{ Compound $\mathrm{A}$ (hydroxyapatite loaded with about $1 \mathrm{mg} / \mathrm{mL}$ doxycycline) } \\
\hline \multirow[t]{3}{*}{ Microbial strains } & \multirow{3}{*}{$\begin{array}{l}\text { Sample of } \\
\text { compound }\end{array}$} & \multicolumn{3}{|c|}{ Zone of inhibition (mm) } \\
\hline & & \multicolumn{3}{|c|}{ The period of incubation (hours) } \\
\hline & & 24 & 48 & 72 \\
\hline \multirow[t]{3}{*}{ Bacillus subtillis } & $\mathrm{C} 1(200 \mathrm{mg})$ & 10 & 11 & 11 \\
\hline & $\mathrm{C}_{2}(500 \mathrm{mg})$ & 14 & 15.5 & 15.5 \\
\hline & $\mathrm{C} 3(2300 \mathrm{mg})$ & 19 & 20 & 20 \\
\hline \multirow{3}{*}{$\begin{array}{l}\text { Pseudomonas } \\
\text { aeruginosa }\end{array}$} & $\mathrm{C} 1(200 \mathrm{mg})$ & 0 & 0 & 0 \\
\hline & $\mathrm{C} 2(500 \mathrm{mg})$ & 0 & 0 & 0 \\
\hline & $\mathrm{C} 3(2300 \mathrm{mg})$ & 0 & 0 & 0 \\
\hline \multicolumn{5}{|c|}{ Compound B (hydroxyapatite loaded with about $2 \mathrm{mg} / \mathrm{mL}$ doxycycline) } \\
\hline \multirow[t]{3}{*}{ Bacillus subtillis } & $\mathrm{Cl}(200 \mathrm{mg})$ & 13 & 14.5 & 14.5 \\
\hline & $\mathrm{C}_{2}(500 \mathrm{mg})$ & 15.5 & 16 & 16 \\
\hline & $\mathrm{C} 3(2300 \mathrm{mg})$ & 24 & 25 & 25 \\
\hline \multirow{3}{*}{$\begin{array}{l}\text { Pseudomonas } \\
\text { aeruginosa }\end{array}$} & $\mathrm{Cl}(200 \mathrm{mg})$ & 0 & 0 & 0 \\
\hline & $\mathrm{C} 2(500 \mathrm{mg})$ & 0 & 0 & 0 \\
\hline & C3 (2300 mg) & 0 & 0 & 0 \\
\hline
\end{tabular}




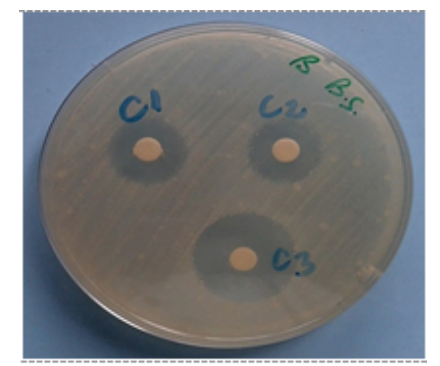

Bacillus subtilis after $48 \mathrm{~h}$

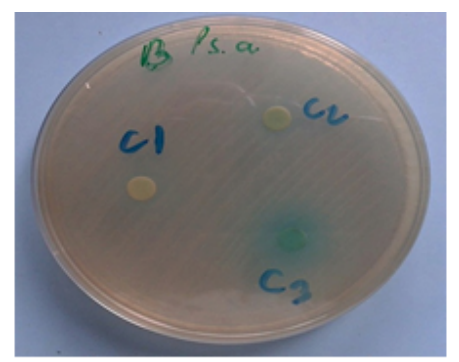

Pseudomonas aeruginosa after $48 \mathrm{~h}$ Pseudomonas aeruginosa after $72 \mathrm{~h}$

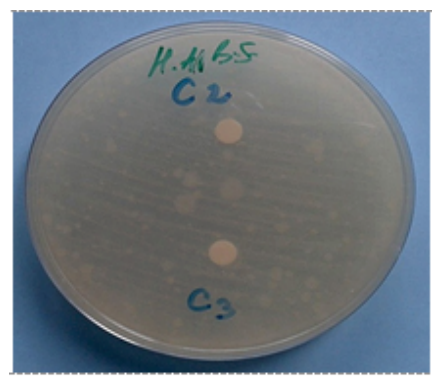

Bacillus subtilis after $48 \mathrm{~h}$

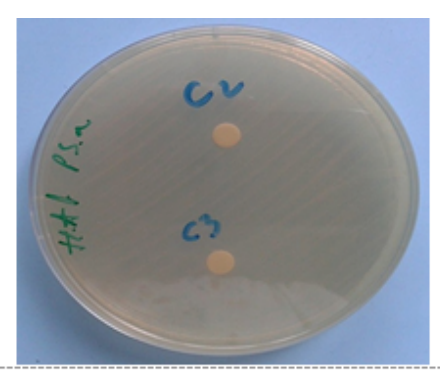

Pseudomonas aeruginosa after $48 \mathrm{~h}$ Pseudomonas aeruginosa after $72 \mathrm{~h}$
Bacillus subtilis after $72 \mathrm{~h}$
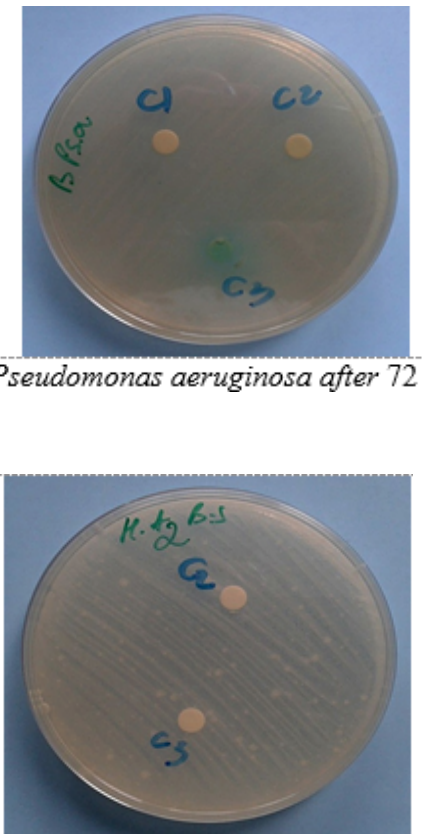

Bacillus subtilis after $72 \mathrm{~h}$

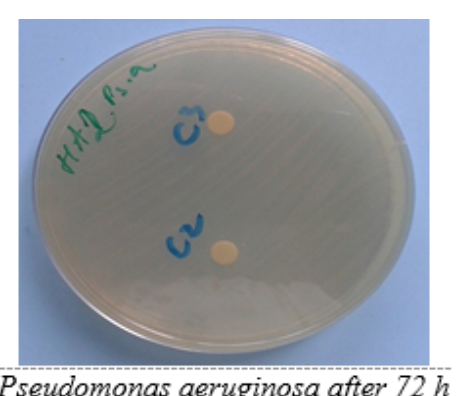

Fig. 10. The inhibitory effect of compound B (HA loaded with about $2 \mathrm{mg} / \mathrm{mL}$ doxycycline) against the growth of the bacterial strains
Table 2

THE INTERPRETATION CRITERIA FOR INHIBITION ZONE DIAMETER ON THE BACTERIAL GROWTH

\begin{tabular}{|l|l|l|}
\hline & $\begin{array}{l}\text { MIC* } \\
(\mu \mathrm{g} / \mathrm{mL})\end{array}$ & $\begin{array}{c}\text { Zone diameter } \\
(\mathrm{mm})\end{array}$ \\
\hline susceptible & $\leq 4$ & $\geq 20$ \\
\hline intermediate & $8-16$ & $15-19$ \\
\hline resistant & $\geq 32$ & $\leq 14$ \\
\hline
\end{tabular}

Fig. 11. The inhibitory effect of pure hydroxyapatite (HA1 and HA2) against the growth of the bacterial strains

A similar behavior was observed for compound B (fig. 10), where the inhibitory effect against Bacillus subtilis is clearly seen after $48 \mathrm{~h}$. The diameter of the zone of inhibition for the compound $\mathrm{B}$ was higher for $\mathrm{Cl}$ and $\mathrm{C} 3$, compared with the values for compound $A$.

The results obtained in figure 11 show the absence of inhibitory effect on the bacterial growth of pure hydroxyapatite.

The interpretation criteria for the inhibition zone diameter (table 2) are made in accordance to the Performance standards for antimicrobial disk susceptibility tests; approved standard- ed. 11th; J anuary 2012 M02-A11, vol. 32, no. 1 (Replaces M02-A10 Vol. 29 No. 1).

\section{Conclusions}

The hydroxyapatite nano and microparticles were prepared by wet-chemical precipitation method using $\mathrm{Ca}\left(\mathrm{NO}_{3}\right)_{2}, 4 \mathrm{H}_{2} \mathrm{O}$ and $\left(\mathrm{NH}_{4}\right)_{2} \mathrm{HPO}_{4}$. The size, morphology and structure of the HA samples were characterized by Scanning Electron Microscopy (SEM), Dynamic Light Scattering (DLS) and Fourier Transform Infrared
Spectroscopy (FTIR). The HA particles with average diameters of $1 \mathrm{im}$ were obtained. The drug loading and release behavior of the HA were also investigated. The drug-loaded HA exhibits a high adsorption capacity and a good drug controlled release property. The antibacterial activity of doxycycline, pure hydroxyapatite and doxycycline-loaded hydroxyapatite was performed against the Bacillus subtilis and Pseudomonas aeruginosa. The study demonstrates that hydroxyapatite particles loaded with doxycycline have an antibacterial effect against Bacillus subtilis, even at the lowest amount of biochemical compound. The strain of Pseudomonas aeruginosa was not sensitive to the doxycycline-loaded hydroxyapatite. The pure hydroxyapatite didn't show any inhibitory effect on the bacterial growth. The doxycycline-loaded HA particles have the potential for application in medicine as promising carriers for the release of various water-soluble drugs.

Acknowledgments: This work was supported by the Ministry of Education from Romania in the frame of the contract research No. 9N/27.02.2009, addendum/2014 (ProjectPN 09.09.04.11/2014). 


\section{References}

1. J AYARAMAN, P., GANDHIMATHI, C., VENUGOPAL, J.R., BECKER D.L., RAMAKRISHNA S., KUMAR D.S., Adv. Drug Delivery Rev., 94, 2015, p. 77 - 95.

2. MATSUMOTO, T., OKAZAKI, M., INOUE, M., YAMAGUCHI, S., KUSUNOSE, T., TOYONAGA, T., HAMADA, Y., TAKAHASHI, J., Biomaterials, 25, 2004, p. 3807-3812.

3. SIBILLA, P., SERENI, A., AGUIARI, G., BANZI, M., MANZATI, E., MISCHIATI, C., TROMBELLI, L., DEL SENNO, L., J. Dent. Res., 85, 2006, p. 354-358.

4. BARROS, J ., GRENHO, L., FERNANDES, M.H., MANUEL, C.M., MELO, L.F., NUNES, O.C., MONTEIRO, F.J ., FERRAZ, M.P., Colloids and Surfaces B: Biointerfaces, 130, 2015, p. 305-314.

5. RAUSCHMANN, M.A., WICHELHAUS, T.A., STIRNAL, V., DINGELDEIN, E., ZICHNER L., SCHNETTLER, R., ALT, V., Biomaterials, 26, 2005, p. 2677-2684.

6. TIAN, B., TANG, S., WANG, C.D., WANG, W.G., WU, C.L., GUO, Y.J., GUO Y.P., ZHU, Z.A, Colloids and Surfaces B: Biointerfaces, 123, 2014, p. 403-412.

7. WANG, Y., HAO, H., LI, Y., ZHANG, S., Colloids and Surfaces B: Biointerfaces, 140, 2016, p. 297-306.
8. PRAMANIK, S., AGARWAL, A.K., RAI, K., GARG, A., Ceram. Int., 33, 2007, p. 419-426.

9. ZHANG, H., DARVELL, B.W., Acta Biomater, 6, 2010, p. 3216-3222. 10. KOUMOULIDIS, G.C., KATSOULIDIS, A.P., LADAVOS, A.K., POMONIS, P.J ., TRAPALIS, C.C., SDOUKOS, A.T., VAIMAKIS, T.C., J Colloid Interf Sci, 259, no. 2, 2003, p. 254-260.

11. SUN, R.X., LU Y.P., CHEN, K.Z., Materials Science and Engineering: C, 29, no. 4, 2009, p. 1088-1092

12. LIU, C., HUANG, Y., SHEN, W., CUI, J., Biomaterials, 22, 2001, p. 301-306.

13. SANTOS, M.H., DE OLIVEIRA, M., DE FREITAS ZOUZA, L.P., MANSUR, H.S., VASCONCELOS, W.L., Mater. Res., 7, 2004, p. 625-630.

14. ZHANG, S. AND GONSALVES, K.E., 1997. J. Mater. Sci.: Mater. Med., 8, 1997, p. 25-28.

15. AFSHAR, A., GHORBANI, M., EHSANI, N., SAERI, M.R., SORREL, C.C., Mater. Design, 24, 2003, p. 197-202.

16. LIU, C., HUANG, Y., SHEN, W., CUI, J., Biomaterials, 22, no. 4, 2001, p.301-306.

17. MONMATURAPO J, N., Journal of Metals, Materials and Minerals, 18, no.1, 2008, p.15-20.

Manuscript received: 12.03 .2018 